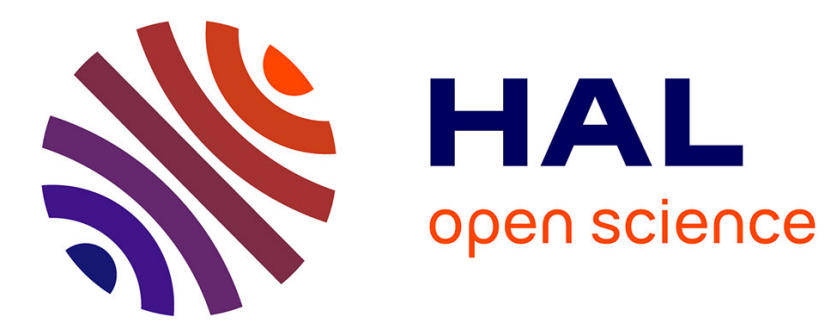

\title{
Ramon de Penyafort's Responses to questions concerning relations between Christians and Saracens: critical edition and translation.
}

\author{
John Tolan
}

\section{To cite this version:}

John Tolan. Ramon de Penyafort's Responses to questions concerning relations between Christians and Saracens: critical edition and translation.. 2012. hal-00761257

\section{HAL Id: hal-00761257 \\ https://hal.science/hal-00761257}

Preprint submitted on 5 Dec 2012

HAL is a multi-disciplinary open access archive for the deposit and dissemination of scientific research documents, whether they are published or not. The documents may come from teaching and research institutions in France or abroad, or from public or private research centers.
L'archive ouverte pluridisciplinaire HAL, est destinée au dépôt et à la diffusion de documents scientifiques de niveau recherche, publiés ou non, émanant des établissements d'enseignement et de recherche français ou étrangers, des laboratoires publics ou privés. 


\section{Ramon de Penyafort's Responses to questions concerning relations between Christians and Saracens: critical edition and translation.}

John TOLAN

\section{Résumé :}

C'est vers la fin de 1234 qu'à la cour pontificale on reçut une lettre du prieur dominicain et du ministre franciscain résidant à Tunis, posant une série de quarante questions concernant la gestion de la communauté catholique de Tunis--il s'agit surtout de savoir si certains péchés valent l'excommunication et s'ils sont mortels ou véniels. Les conciles œcuméniques et la législation pontificale avaient certes fixé les règles en principe, mais n'avaient évidemment pas envisagé tous les cas de figure que rencontraient les frères de Tunis au jour le jour. Raymond de Penyafort, confesseur et pénitentiaire au Pape Grégoire IX, explique que le pape donna sa réponse à chacun des questions et que lui, Raymond, les fit transcrire et leur les envoya. Les questions et réponses ont été préservées dans un texte appelé les Responsiones ad dubitabilia circa communicationem christianorum cum sarracenis, daté du 19 janvier 1235 . Chaque section contient, d'abord, une question que le prieur dominicain et le ministre franciscain avaient posée, suivie de la réponse du pape, transcrite par Ramon. Les questions traitent de la légitimité (ou non) de toute une série de transactions, de la vente des clous aux musulmans au baptême secret de leurs enfants. Ce texte nous apporte des informations non négligeables sur la communauté latine de Tunis; on se rend compte tout d'abord que cette communauté est importante et très hétéroclite. Il y a d'abord les marchands: génois, pisans et "espagnols" (sans doute catalans). Il y a des clercs: les Franciscains et Dominicains, bien entendu, mais aussi des prêtres des villes marchandes, associées avec les funduqs des celles-ci. Il y a des mercenaires, des croisés, des personnes converties à l'Islam, des captifs, des esclaves, même des personnes qui servent de gage pour des emprunts.

Cet article consiste en une introduction au texte, l'édition critique du texte latin, et des traductions anglaises et françaises.

\section{Abstract :}

Towards the end of 1234, a letter arrived at the papal curia from the Franciscan minister and the Dominican prior residing in Tunis, posing a series of forty questions concerning their ministry to the Catholic community of Tunis-primarily on whether certain sins called for excommunication, or whether they were mortal or venial. The ecumenical councils and pontifical decrees had indeed established the rules in principle, but they had not imagined all the particular cases that these friars encountered in Tunis. Raymond of Penyafort, confessor and penitentiary to Pope Gregory IX, explains that the pope gave his answer to each of these questions and that he, Raymond, wrote them down and sent them to the two friars. Questions and answers are preserved in a text known as the Responsiones ad dubitabilia circa communicationem christianorum cum sarracenis, dated January 19th 1235 . Each section contains first a question posed by the friars and then the pope's response, transmitted by Raymond. The questions concern the legality (or not) of a whole series of transactions with Muslims: from selling them nails to secretly baptizing their children. This text offers us precious information on the Latin Christian community of Tunis, which is numerous and diverse. There are merchants: 
Genoans, Pisans and "Spaniards" (no doubt Catalans). There are clerics: Franciscans and Dominicans, of course, but also the priests from the maritime cities, associated with their funduqs. There are mercenaries, crusaders, converts to Islam, captives, slaves, even persons serving as pawn for loans.

This article consists of an introduction to the text, a new critical edition of the Latin text, and English and French translations.

\section{Introduction}

Raymond of Penyafort is one of the most prolific and important canon lawyers of the thirteenth century. Born in Catalonia, he studied law in Bologna (1210-19); there, according to tradition, he encountered St. Dominic and joined the Order of Preachers in 1222. It was probably between 1222 and 1226 that he composed his Summa de paenitentia, a sort of law code for confessors, in the tradition of the Bologna law commentaries. When he joined the papal curia of Gregory IX in 1230, the pope asked him to compile the Decretals, a major collection of pontifical decrees; the work was destined to become one of the pillars of canon law. He completed the Decretals in 1234; Gregory promulgated them in his bull Rex pacificus on September $5^{\text {th }} 1234 .^{1}$

In 1238 Raymond was elected Master General of the Dominican order; he supervised the revision of the rule of the order. He retired from the head of the order in 1240 and returned to Barcelona, where he became a key advisor to King James I. He convinced the king to make Muslims and Jews listen to Dominican missionaries in their synagogues and mosques. He was influential in the promotion of mission to the infidels, notably in encouraging the king to organize a public disputation between Friar Pablo Christiani and Rabbi Nachmanides in Barcelona in 1263. 2

Towards the end of 1234, a letter arrived at the curia from the Franciscan minister and the Dominican prior residing in Tunis, posing a series of forty questions concerning their ministry to the Catholic community of Tunis-primarily on whether certain sins called for excommunication, or whether they were mortal or venial. The ecumenical councils and pontifical decrees had indeed established the rules in principle, but they had not imagined all the particular cases that these friars encountered in Tunis. Raymond explains that the pope gave his answer to each of these questions and that he, Raymond, wrote them down and sent them to the two friars. Questions and answers are preserved in a text known as the Responsiones ad dubitabilia circa communicationem christianorum cum sarracenis, dated January 19th 1235 . Each section contains first a question posed by the friars and then the pope's response, transmitted by Raymond. The questions concern the legality (or not) of a whole series of transactions with Muslims: from selling them nails to secretly baptizing their children. This text offers us precious information on the Latin Christian community of Tunis, which is numerous and diverse. There are merchants: Genoans, Pisans and "Spaniards" (no doubt Catalans). There are clerics: Franciscans and Dominicans, of course, but also the priests from the

\footnotetext{
${ }^{1}$ L. Robles, Escritores dominicos de la Corona de Aragon, siglos XIII-XV (Salamanca, 1972), p. 13-57 ; J. M. Coll, «San Raymundo de Peñafort y las misiones del norte africano en la edad media », Missionalia hispanica, 5 (1948), 417-457; C. Longo, ed., Magister Raimundus: atti del convegno per il IV centenario della canonizzazione di San Raimondo de Penyafort (1601-2001), (Rome, 2002); S. Kuttner, "Raymond of Penyafort as editor: The 'decretales' and 'constitutiones' of Gregory IX," Bulletin of Medieval Canon Law 12 (1982) 65-80; A. García Y García, Iglesia, sociedad y derecho (Salamanca, 1985), 79-115.

2 See R. Chazan, Barcelona and Beyond: The Disputation of 1263 and its Aftermath (Berkeley, 1992).
} 
maritime cities, associated with their funduqs. There are mercenaries, crusaders, converts to Islam, captives, slaves, even persons serving as pawn for loans. ${ }^{3}$

This text offers a unique glimpse of the workings of the Latin Christian community in Tunis and of papal responses to the problems posed by Christians living in Muslim lands. In the first place, it provides documentation of trade practices of European (principally Italian and Catalan) merchants in Ifrīqiya (roughly what it now Tunisia). In this it complements other important documentation: the treaties (in Latin and Arabic) between European and Maghribi rulers; and the great number of trade documents (primarily contracts) in the archives of Pisa, Genoa, Venice, Barcelona, and other cities. What is particularly intriguing about this document is that it places these issues clearly in the framework of papal prohibitions of certain kinds of trade with Muslims: one sees some merchants openly flouting these prohibitions, others trying to respect them or making excuses for their non-respect of them. The pope emphasizes that certain types of trade incur the penalty of excommunication, as had been established by the ecumenical councils of Lateran III (1179) and Lateran IV (1215). In particular, those who sell weapons, ships, or iron or wood that could be used to make weapons or ships (Responsiones $\mathbb{1} 1$ ). Those who were unaware of these prohibitions are still excommunicated; they can however be absolved and are given lighter penance

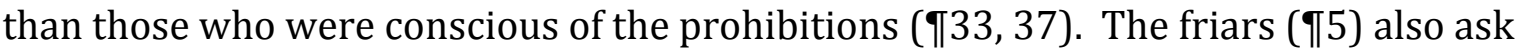
about those who take swords, knives or other weapons into "lands of Saracens" without intent to sell (but only for their own self-defense) and who subsequently sell them to Saracens. They too, are excommunicated, as are hired hands on ships of traders involved in illicit commerce, though the latter can be given lighter penance, at the discretion of the confessors ( $(40)$. Yet other cases are less clear-cut: selling of saddles and other equipment for horsemen ( $(2)$; selling of food ( $\$ 3$ ). Some Christian merchants transported victuals from one "Saracen" port to another ( $\ 4)$; some took iron from one Saracen port to another ( $\mathbb{2 3}$ ); some transported armed Saracens ( $\mathbb{1 2 4}$ ). The Friars asked if it was licit to sell ligna parvicula (tiny pieces of wood -25)? They asked the same questions about hemp, pitch and flax, materials essential for building and equipping ships ( $(26)$. Iron and weapons were banned, but what about cultellos parvissimos et clavos minutissimos, tiny knives and teensy-weensy nails ( 127$)$ ? In the vast majority of cases, Raymond, in the name of the pope, responds that such traders are excommunicated if and only if their trade helps Saracens who are fighting against Christians or works otherwise to the detriment of Christians; in other cases, such trade is licit.

The Responsiones are also an important document in the early history of the Dominican and Franciscan orders, in two ways: they show the increasing presence of those orders beyond the borders of Catholic Europe and the role that these orders play in the papacy's effort to more forcefully and effectively exercise its authority. Before becoming Pope Gregory IX, cardinal Hugolino knew both Dominic and Francis and was cardinal protector of their two orders. As pope, he had both men canonized and took an active interest in the consolidation and expansion of both orders. The document provides testimony of the attempts of the Papacy and the mendicants to extend their

${ }^{3}$ Much of what follows is based on the two following articles: J. Tolan, "Taking Gratian to Africa: Raymond de Penyafort's legal advice to the Dominicans and Franciscans in Tunis", in A. Husain \& K. Fleming, eds., $A$ Faithful Sea: The Religious Cultures of the Mediterranean, 1200-1700 (Oxford: One World, 2007), 47-63; J. Tolan, "Marchands, mercenaires et captifs: le statut légal des chrétiens latin en terre d'islam selon le juriste canonique Ramon de Penyafort (XIIIe s.)", in S. Boisselier, F, Clément \& J. Tolan, eds., Minorités et régulations sociales en Méditerranée médievale (Rennes: Presses Universitaires de Rennes, 2010), 223-34. For more detailed analysis of some of the articles in the Responsiones, see the corresponding entries in the RELMIN database: http://www.cn-telma.fr/relmin/auteur1593/. 
reach into new realms; here as elsewhere (e.g., the University of Paris at the same time), the mendicants drew sharp resistance from secular clergy who did not want to see their prerogatives trampled. The friars are not the only Christian clergy present in Tunis. They at times come into conflict with priests who resent their presence and who refuse to recognize their authority. The friars ask the pope how they should proceed in the case of certain married fratres spirituales ( $(12)$ present in Tunis before the arrival of the friars. Such marriage is in clear violation of the principles of the so-called "Gregorian Reform" of the eleventh century. This is the same sort of problem faced in the wake of the crusades (particularly the fourth crusade) which brought Latin clerics into contact with married clergy of the eastern churches. The response here is that such men should be separated from their wives if possible, but otherwise they may remain married; in no case should new marriages of clerics be contracted.

Another fundamental issue of the reform movement was the immunity of clerics from lay justice and punishment. The friars mention the case of "some people" who seize "clericos latrones" (thieves who are clerics) and whip them ( $\mid 28)$. The question is whether these people are to be excommunicated and whether the friars can absolve them. The pope responds that yes, they are to be excommunicated, and that yes, the friars can absolve them. Hence the principle of clerical immunity is affirmed, but those laymen who have punished errant clerics can receive absolution. Other questions involve the pope's delegation of powers to the friars. Pope Honorius III had conferred upon them the power to grant absolution to excommunicates, in cases where the persons could not easily (commode) come to Rome to receive absolution directly from the pope ( $(20)$. The friars ask, what does commode mean? In response, Gregory confirms the powers granted by his predecessor and defines what commode means here: the friars may absolve excommunicates who are prevented from traveling to Rome by illness, old age, poverty. Others should go to Rome to receive absolution from the pope. In a similar vein, the friars have received the power of according absolution in extremis ( $(31)$. They ask what that means: does a fever or dysentery qualify? The pope answers that a person should be considered in extremis only if there is real danger of death.

Moreover, the Responsiones give us a unique glimpse at the richness and complexity of the European catholic community in Tunis that the friars seek to serve: not only the Italian and Catalan Merchants, but also mercenaries, crusaders, fugitives, captives, or pilgrims on their way to Jerusalem. We find, in particular, a number of marginal persons whose existence is seldom registered in other contemporary documents, in Arabic or Latin: renegades, slaves, converts, mixed couples.

Of particular interest are a series of questions involving conversion. In general, of course, conversion in Muslim Tunis is envisioned in only one direction: to Islam: Christians who in "fear of the Saracens" ( $(16)$ participate in secret night-time services may be nominal Muslims who have surreptitiously returned to Christianity. Only one passage ( $(99)$ deals with the actual baptism of Muslims. Some Christian servants or slaves of Muslims took care of Muslim children. They asked the Friars whether they could and should secretly baptize these children: if they then died before the age of discretion, they would be saved. The pope responds that they should be baptized. We may presume, then, that a number of Muslim children of $13^{\text {th }}$-century Tunis were secretly baptized by their Christian nannies.

One of the friars' questions ( $\mathbb{1 1 0}$ ) involves those who were Christians and subsequently converted to Islam. Some converted when they were young, some adult; some slave, some free: many of them converted, say the friars, largely because they were ignorant concerning the articles of the faith. Such apostasy, in Christian Europe, is illegal-potentially a capital crime. But of course in Muslim Tunis, there is no question 
of punishing them, as they are beyond the reach of Christian princes and indeed of spiritual penalties such as excommunication (since they have voluntarily removed themselves from communion with the Church, according to Gratian's Decretum) ${ }^{4}$. The concern here is for their relatives who have remained Christian. According to Canon law, Christians ought to shun the company of heretics; ${ }^{5}$ exceptions are allowed for those who seek to bring them back to the Catholic fold. Yet the friars realize that if they try to prohibit Christians in Tunis from maintaining contact with their Muslim relatives, they will have little luck, and will most likely only push them to apostatize as well. "It seems to us that they cannot easily abstain from frequenting the above-mentioned people, either because they love them according to the flesh, as their children, or because they receive food from them." The pope answers that they may frequent these Muslim causa correctionis vel necessitatis - in other words, either in order to try to bring them back into the Christian fold or for material necessity. By applying Gratian's legislation concerning heretics to Muslims, Raymond and Gregory place Islam-in legal and practical terms - in the category of heresy. This is in line with much contemporary theological reflection on Islam, particularly the work of Latin Christian polemists against Islam in the twelfth and thirteenth centuries. ${ }^{6}$

One group of Christians remains difficult to identify: the "aromes" ( $\mathbb{1 3}$ : variant MS readings are arrones or atronies). Who are they? All we learn from this passage is that the friars are ministering to them ("quorum curam gerimus") and that they are prone to make oaths. The term (or variants on it) appear in other works of Raymond. In his Summa de paenitentia, Raymond explains that the atronii are Christians living under Muslim rule. He affirms that some of them participate in Muslim rites: they proclaim that "Mahumatus" is a prophet or they kiss the "sepulcrum Almeadi". 7 The latter is a reference to the pilgrimage cult of the Mahdi Ibn Tumart, founder of the Almohad movement, at his tomb in Tinmāl (near Marrakech), which became an important means for the Almohad caliphs to affirm their legitimacy as successors of Ibn Tumart. ${ }^{8}$ Raymond asserts that many of these atronii behave in public as Saracens and in private as Christians. Raymond says that these people are apostates if they do these things out of a desire to revere God (that is, if they believe in the efficacy of these non-Christian practices) but merely commit a mortal sin if they do so out of fear. In a letter to the Minister General of the Dominican order, Raymond argues in favor of the Dominican missions to the Saracens by presenting six "fruits" gleaned from such missions. The second fruit is "among the aramos who are Christians but servi of the Saracens and do not understand any language but Arabic, who desire the [presence of the] friars with a great yearning, so that they might be instructed and strengthened by them" 9 In the text

${ }^{4} \mathrm{C} 24$ q 1 c4-5. For analysis of C24 and references to a new critical edition, see Anders Winroth, The Making of Gratian's Decretum (Cambridge: Cambridge University Press, 2000), chap 2, "Heresy and Excommunication: Causa 24," pp. 50-92.

5 "Hereticorum consortia a catholicis sont fugienda" C 24 q1 c2.

${ }^{6}$ See J.Tolan, Saracens: Islam in the Medieval European Imagination (New York: Columbia University Press, 2002).

${ }^{7}$ Raymond of Penyafort, Summa de paenitentia 1.7.7 (col. 334-35): "Ecce multi christiani resident in quibusdam civitatibus sarracenorum, et maxime illi qui vocantur atronii; aliquis illorum profitetur Mahumatum nuntium esse Dei, sicut et sarraceni faciunt ad laudem et venerationem illius quem colunt et venerantur pro sancto. Alius osculatur sepulcrum Almeadi, quasi ex reverentia, ac si esset sanctus. Alii in publico gerunt se pro sarracenis et in occulto pro christianis".

${ }^{8}$ See P. Buresi, "Les cultes rendus à la tombe du Mahdī Ibn Tūmart à Tinmāl", in F. Déroche et J. Leclant eds., Monuments et cultes funéraires d'Afrique du Nord, (Paris, 2010), p. 185-231.

${ }^{9}$ «Secundo, inter Aramos, qui sunt Christiani, sed Sarracenorum servi, nec intelligunt nisi linguam Arabicam et desiderio magno desiderant fratres, ut instruantur et confirmentur ab ipsis." The letter is preserved in Gerardus de Fracheto, Vitae fratrum Ordinis Praedicatorum necnon Cronica Ordinis ab anno 
of this letter we find the term aramos, while in the Summa de paenitentia is the term atronii. Both terms are found as variant readings, in the Responsiones, of aromes, so we may presume that all these references are to the same group and that European scribes unfamiliar with the term produced the variant spellings. If these three passages indeed refer to the same group of Christians, this provides evidence of Arabic-speaking Christian communities in North Africa (in particular in Ifriqiya) in the thirteenth century. Raymond presents them as the "servi" or the Saracens: the term could mean slaves in a strict legal sense but could also designate simple subservience, corresponding with the status of dhimmi. Some of them are apparently cryptoChristians who publicly practice Islam: it is tempting to see here the results of forced conversion to Islam under the Almohads, though this is of course conjecture. The two friars in Tunis claim to have some sort of direct responsibility towards this aromes. Does it imply that some sort of ecclesiastical authority had been granted by the Hafsid ruler? Does this mean that the Aromes lacked their own clerics? We have seen that the friars mention married fratres spirituales ( $\$ 12)$ present in Tunis before their arrival, which does suggest the existence of a local clergy. In any case, these brief allusions suggest that indigenous Arabic-speaking communities survived in the Maghrib, albeit precariously, well into the thirteenth century.

The following section ( $(11)$ deals with the problem of mixed marriages. While it is not legal for a Christian to marry a non-Christian, the question here is what happens when one member of a married Christian couple labatur in haeresim, slides into heresy-in other words (in this context) converts to Islam (here again, Islam is treated as heresy). Gratian echoes earlier church legislation in strictly prohibiting marriage between Christians and non-Christians. Yet exceptions are made in cases of conversion: Causa 28 of the Decretum deals with the case of a married infidelis who converts to Christianity and whose spouse remains infidelis. Gratian affirms that it is permitted for the new Christian to separate from his non-Christian spouse, but also that she or he may remain married if she or he so wishes. The key distinction here is to know whether the now Christian member of the couple can remain married to the infidel spouse without contumelia creatoris, "insult to the creator". This is a direct reference to Decretum C28 q2 c2: when the non-Christian spouse hates Christianity, and is guilty of insult to the creator, the Christian spouse may not only separate from the infidel, but may marry anew. The bible prohibits divorce; separation or annulment is allowed on specific grounds, including consanguinity and adultery. The Decretum affirms that contumelia creatoris is a sort of spiritual adultery, far worse than the mere physical kind, and that it is therefore grounds for separation and annulment of marriage. Raymond and the pope apply Gratian's ruling concerning conversion of the marriage of a convert to Christianity to the case of mixed couples where a Christian has converted to Islam.

These two cases in particular show a willingness to creatively engage with the traditions of canon law in order to find solutions to practical problems. Some Christians in Tunis are clearly going to continue to convert to Islam, and their spouses and other relatives are going to continue to socialize with them. Raymond and the pope were willing and able to find legal justifications for them to do so. Some Muslim muftis were adept at ijtihad, adapting the shari'a to the changing needs of Muslims, grounding their concessions in the textual traditions of Muslim law. Clearly some canon lawyers could do the same; the Dubitabilia provide striking examples of thirteenth-century Christian ijtihad. This text is thus not only of value as a source for the social history of a diverse 
and poorly-documented community of Christian Europeans in thirteenth-century North Africa, it is also a testimony to the malleability and creativity of legal traditions.

\section{Manuscripts}

There are 7 extant manuscripts of the Dubitabilia.

\section{Y New Haven, Yale University, Beinecke rare book and manuscript library, Marston MS 127, f. 135v, col b. - 137r, col a}

$13^{\text {th }}$ c.; parchment, ff. i (early parchment flyleaf) +138 . Measures $168 \times 114 \mathrm{~mm}$. 2 columns, 40 lines. Double outer and single inner vertical bounding lines with an additional ruling between columns. Single upper horizontal ruling. Ruled in lead or crayon. Remains of prickings in upper, lower and outer margins. Fine flourished initial, 5-line, divided red and blue, with penwork designs in both colors and long marginal tail of letter Q, f. 1r. Smaller flourished initials incorporating the heads of bird-like grotesques and cross-hatching designs. 1-line initials alternate red and blue for chapter lists. Paragraph marks and running headlines in red and blue. Rubrics throughout; instructions for rubricator along outer edges of leaves, some perpendicular to text.

Middle of the 13th century. Written in Italy or Southern France, according to Shailor; in Spain, according to Faye \& Bond. Purchased from Enzo Ferrajoli in Geneva in 1957 by L. C. Witten, who sold it the same year to Thomas E. Marston. The MS contains part of Raymond of Penyarfort's Summa de poenitentia et matrimonio, selections from the Decretales of Gregory IX, and various unidentified texts on canon law.

This is the oldest surviving manuscript of the text and contains what is probably the best text; it is complete, though the scribe occasionally makes errors due to inattention (substituting arma for naues or lignamina for legumina). I have used this as the base manuscript and followed its spelling and word order, correcting it only when other manuscripts offered a clearly better reading.

Barbara Shailor et. al., Catalogue of Medieval and Renaissance Manuscripts in the Beinecke Rare Book and Manuscript Library, Yale University, vol 3 (Binghamton, 1992), 235-37.

C. Faye \& W. Bond, Supplement to the Census of Medieval and Renaissance Manuscripts in the United States and Canada (New York, 1962) p. 79, no. 127.

\section{E Florence, Biblioteca Medicea Laurenziana, Plut. 24.6, fol 79rb-80ra}

$13^{\text {th }}$ c. Parchment, $83 \mathrm{ff}, 32 \times 24 \mathrm{~cm}$. Contains Raymond's De penitentia. No signs of provenance or previous ownership on MS ; this is a fairly luxurious illuminated MS probably destined for the library of a Dominican convent.

3. F Florence, Biblioteca Nazionale, Conventi soppressi I.X.49, fol 162ra-163vb Parchment, 175ff, 14th cent. 18x12 cm (small modest "pocket" codex; could be carried around by friar).

From the Dominican convent of San Marco, Florence.

Contains texts on virtues and vices, largely from a monastic/mendicant perspective. The last collection of texts, in which the Responsiones are inserted, show a concern in particular for questions of excommunication as a punishment; this may explain why certain chapters of the Responsiones are omitted.

Indici dei manoscritti scelti nelle bibliotheche monastiche del dipartimento dell'Arno dalla commissione degli oggetii d'arti e scienze e dalla medesima rilasciati alla Pubblica Libreria Magliabechiana (hand-written catalogue, no date), p.145-46.

Di Benedetto, Filippo, Review of Berthold Ullman \& Philip Stadter, The Public Library of Renaissance Florence: Niccolò Niccoli, Cosimi de' Medici and the Library of San Marco, in Studi medievali xiv (1973), 947-60 (esp. 954-55)

Kaeppeli, Scriptores Ordinis Praedicaatorum 3:285. 


\section{O Oxford, Bodleian Library MS Canon Mis. 269, f. 206-210}

$15^{\text {th }}$ c parchment, $135 \times 106 \mathrm{~mm}, 274 \mathrm{ff}$.

Clear, very readable MS, in various gothic hands, with different print sizes and rulings (perhaps originally different works bound together later; binding in leather with paper end papers, $17^{\text {th }}$ $18^{\text {th }}$ c.). This quite small MS seems to be a pocket book for friars, for consultation on issues of penance. Final text in Italian, suggesting Italian provenance of MS. Contains various works on penance, mostly by Franciscan authors, including Angelus de Perusio (fl mid-15 th c.).

H. O. Coxe, Catalogi codicum manuscriptorum Bibliothecase Bodleianae, pars III: Codices Codices graecos et latinos canonicianos complectens (Oxford, 1854), 638-9.

\section{P Pisa, Biblioteca del Seminario MS 100, f. 42v-45v}

$15^{\text {th }} \mathrm{c}$ parchment, $72 \mathrm{ff} 19.5 \times 13.5 \mathrm{~cm}$.

Several different hands, different rulings ( 2 columns throughout; 30 lines per column at beginning, 26 at end, where writing is larger). This undecorated manuscript in clear gothic hand was the base MS for Ochoa's 1976 edition. It is defective in parts, due to omissions, in particular part of question 37 and all of question 38. Vitelli gives fairly detailed listing of incipits, but does not identify any of the texts. The MS contains various texts dealing with canon law, particular questions of penance.

G. Tamburini, Inventari dei manoscritti d'Italia 24: Pisa, Biblioteca Cateriniana del Seminario (Florence, 1917), p. 81

C. Vitelli, "Index codicum latinorum qui pisis in bybliothecus conventus S. Catherinae et universitatis adservantur", Studi italiani de filologia classica 8 (1900), 321-427 (esp. 3756)

\section{V Vatican, Bibl. Ap. Ottob. lat. 45, fol. 103v-104}

$13^{\text {th }}$ c., parchment. Contains works on penance and confession. Includes Raymond's Decretales novae.

Xavier Ochoa \& Aloiso Diaz, Universa bibliotheca iuris, volumen 1, S. Raimundus de Pennaforte, tomus C (Rome: Commentarium pro religiosis, 1978), p. cxxxvi.

\section{A Prague, Bibl. Kapit. K 12, fol 16v-18v}

$14^{\text {th }}$ c., parchment. A collection of texts concerning canon law and penance, including selected decretals of Gregory IX and texts by Johannes Andreae and Johannes de Capito. This manuscript contains a defective version of the text, with many omissions and errors (as indicated in the notes to the edition).

J. Von Schulte, "Die canonischen Handschiften der Bibliotheken Prags", Abhandlungen der $k$. böhemischen Gesellschaft der Wichenshaften 6 (1868), 87-105. (online at http://books.google.fr/books?id=831FAAAAcAAJ\&lpg=PA99\&ots=kuksjgvALG\&dq=et\% 20si\%20postea\%20repetuntur\%20\%20non $\% 20$ redduntur\&pg=PP5\#v=onepage \&q\&f=f alsef )

\section{Earlier editions}

There have been five previous editions of the Dubitabilia. 
1. J. Von Schulte, "Die canonischen Handschiften der Bibliotheken Prags", Abhandlungen der k. böhemischen Gesellschaft der Wichenshaften 6 (1868), 97-102. Edition based on MS A. (online at

http://books.google.fr/books?id=831FAAAAcAAJ\&lpg=PA99\&ots=kuksjgvALG\&dq=et $\% 20$ si $\% 2$ 0postea\%20repetuntur\%20\%20non\%20redduntur\&pg=PP5\#v=onepage\&q\&f=falsef )

2. F. Balme, C. Paban \& I. Collomb, Raymundiana seu documenta quae pertinent ad S. Raymundi de Pennaforti vitam et scripta, Monumenta Ordinis Praedicatorum Historica 4 (Rome, 1898), p. 29-

37. Based on MSS A \& F.

3. A. López, La provincia de España de los frailes menores (Santiago de Compostela, 1915), p. 36876. Based on MS E.

4. José Rius Serra, Diplomatario : Documentos, Vida antigua, Crónicas, Procesos antiguos (Barcelona: Universidad de Barcelona, Facultad de derecho ,1954), p. 22-28. Reprints edition of F. Balme, C. Paban \& I. Collomb (no. 2, above)

5. Xavier Ochoa \& Aloiso Diaz, eds., Dubitabilia super communicationem Christianorum cum Sarracenis, in Universa bibliotheca iuris, volumen 1, S. Raimundus de Pennaforte, tomus C (Rome: Commentarium pro religiosis, 1978), cols 1024-36.

This edition is based on that of Rius ("Documenta directa haurimus de Diplomatario edito a J. Ríus"), with a critical apparatus referring to variant readings in the six manuscripts that the editors consulted (they did not know of MS Y). They show a preference for the readings of MS P, even though that MS, as noted above, is defective in places. They also "modernize" (or rather classicize) the medieval spellings of the MSS. Ochoa's \& Diaz's edition of Raymond's works provoked sharp criticism from A. García y García, ${ }^{10}$ who describes Ochoa's \& Diaz's methodology as "more scholastic that historical." Far from being a critical edition, he affirms that they produce a "texto mixtificado, que hasta ahora nunca había existido como tal". With no scientific criteria for establishing the text, no clearly stated policy for choosing a manuscript as the base of each text, they produce a text which corresponds to "el texto que los editores desearían que San Raimundo hubiese escrito siete siglos antes".

\section{Editorial principles}

Given the shortcomings of the five earlier editions, and given the fact that their editors did not have access to $\mathrm{Y}$, the oldest and in many respects best manuscript of the text, a new critical edition is needed.

I have used MS Y, the oldest and for the most part most reliable MS, correcting the scribes' occasional errors when other manuscripts offer a clearly better reading. I have noted variant readings in the notes. I have not noted minor variants such as inversion of word order, substitution of synonyms for common words (uel/siue, an/utrum, etc.), or minor variations of spelling (saracenus/sarracenus, etc.)

The edition is accompanied by my translation into English and by Laurence Foschia's French translation.

\footnotetext{
${ }^{10}$ A. García y García, “¡No es esto! Glosa a una nueva edición de las obras de San Raimundo de Peñafort”, Revista Española de Derecho Canónico 35 (1979), 187-196.
} 


\section{Critical edition of Latin text of the Dubitabilia}

De quibusdam dubitabilibus ${ }^{11}$

Dilectis ${ }^{12}$ in Christo fratribus J. ${ }^{13}$ priori de ordine predicatorum et G. ${ }^{14}$ de ordine fratrum minorum ministro in regno tunicii commorantibus frater raymumdus, domini pape penitentiarius, salutem in domino. Postulastis per apostolicam sedem edoceri quid in subsequentibus tenere articulis debeatis. Perlectis itaque coram domino papa subscriptis articulis, responsiones ipsius, quas deliberatione habita edidit cuilibet articulo, duxi de speciali mandato suo ${ }^{15}$ fideliter subnectendas ${ }^{16}$, ut in foro penitentiali iuxta tenorem ipsarum intrepide iudicetis.

[1. $]^{17}$ Cum ex constitutione domini Innocentii sint excommunicati qui uendunt naues et deferunt arma uel ferrum uel impendunt aliquod auxilium sarracenis, quid est quod $^{18}$ ianuenses uendunt naues et maxime ueteres sarracenis, dicentes hoc sibi non fuisse ${ }^{19}$ prohibitum a prelatis suis? ${ }^{20}$

Respondemus: qui deferunt naues ${ }^{21}$ uel lignamina galearum, arma uel ferrum sunt excommunicati, quocumque tempore hoc faciant, et hoc per utrumque concilium. Qui uero alia deferunt in dispendium terre sancte sunt excommunicati per ultimum concilium. Uel ${ }^{22}$ si ad impugnandum christianos, sunt excommunicati per primum ${ }^{23}$ lateranense concilium.

[2.] Similiter yspani dant uel uendunt calcaria, frena, et sellas, de quibus dubitamus utrum sint ${ }^{24}$ arma computanda.

Respondemus: si tempore guerre hoc faciunt, excommunicati sunt.

[3.] Item, si sub nomine auxilii continent uictualia, ut dicitur quid est quod yspani uendunt arietes et oues et huius, pisani et ianuenses ${ }^{25}$ frumentum, uinum et legumina ${ }^{26}$, castaneas, auellanas et huius sarracenis, dicentes talia non esse prohibita $\operatorname{sibi}^{27}$ a prelatis suis, et ideo in dubitationem inducimur utrum predicti omnes sint excommunicati.

\footnotetext{
${ }^{11}$ Quedam consultationes domini pape et earumdem responsiones $(\mathrm{E})$; Incipit casus fratris raimundi (P) ; Incipit quedam declaratio (O) ; Incipiunt noui decretales a magistro Remundo (A).

12 Dilectis ... domino; F: Fratribus commorantibus apud tuniĉ frater Raymundus pape premarius salutum.

${ }^{13}$ n. $(\mathrm{A}, \mathrm{E}, \mathrm{V}) ;<$ omit $>(\mathrm{O}, \mathrm{P})$.

${ }^{14}$ n. (A, E, V); <omit> (O, P).

${ }^{15} \operatorname{Sic}(\mathrm{A})$

${ }^{16}$ Subnotandas $(\mathrm{A})$

17 The questions not numbered in MSS; I have numbered them here for ease of reference.

${ }^{18}$ Quid est quod: quicumque (V).

${ }^{19}$ Fuisse sibi (V)

${ }^{20}$ The text of A is somewhat garbled: Cum ex constitutione domini Innocentii sint excommunicati qui uendunt naues et maxime ueteres et deferunt arma uel ferrum uel impendunt aliquod auxilium et quodcumque Ianeum sarracenis, dicentes hoc sibi non fuisse prohibitum a prelatis suis?

${ }^{21}$ arma (Y); <omit $>$ (F)

${ }^{22}$ Vel ... concilium; <omit $>$ (F)

${ }^{23}$ ultimum $(\mathrm{Y})$

${ }^{24} \operatorname{Sint} \sin t(\mathrm{~A})$

${ }^{25}$ pauenses $(0)$

${ }^{26}$ lignamina $(\mathrm{Y})$

${ }^{27}$ Eis (V)
} 
Respondemus: utique sunt tempore guerre huius uenditores sarracenis qui pugnant cum christianis ${ }^{28}$, et hoc per primum lateranensem concilium.

[4.] Item, quidam christiani mercatores honerant naues suas anona et aliis uictualibus in quibusdam partibus sarracenorum ubi est fertilitas, et portant in alias partes sarracenorum facientium guerram cum ${ }^{29}$ christianis. Qui umquam ${ }^{30}$ sarraceni fuissent forsitan destructi, tum ex caristiam tum esset guerra, nisi per huius mercatores eis fuisset subuentum in uictualibus. ${ }^{31}$ Cum igitur huius deportatio uictualium maximum sit auxilium sarracenis, siue sit guerra siue non, querimus utrum sint excommunicati tales.

Respondemus: sunt utique, secundum proximam responsionem.

[5.] Item, utrum sic sit excommunicatus qui portat arma, gladium uidelicet, lanceam uel cultellum uel huius in terram sarracenorum, non cum proposito uendendi, sed ad sui defensionem, et postmodum, occasione ${ }^{32}$ pecunie $^{33}$, uendit eadem sarracenis.

Respondemus: sunt excommunicati.

6. Item, utrum sint excommunicati qui uendunt christianos sarracenis, maxime cum tales, postquam uenduntur, a sarracenis compelluntur fieri sarraceni pro maiori parte. $^{34}$

Respondemus: non sunt excommunicati, set mortaliter peccant.

7. Item, quidam furantur iudeos uel sarracenos, et maxime feminas, et ducentes eas in terram sarracenorum pro coactionem ${ }^{35}$ uel alias faciunt eas profiteri coram sarracenis, quod ${ }^{36}$ sint christiani uel christiane, et sub nomine christiano uendunt eos uel eas sarracenis. ${ }^{37}$ Querimus utrum tales sint excommunicati propter iniuriam quam faciunt nomine christiano in huius uenditione.

Respondemus: non sunt excommunicati ${ }^{38}$ sed mortaliter peccant.

8. Item, utrum sint excommunicati milites christiani uel allii, qui conuersantes cum sarracenis ${ }^{39}$, obligant uel impignorant ${ }^{40}$ uiros uel feminas de familiis suis sarracenis, necessitate compulsi, et maxime qui eos obligant nec credunt se posse sufficere ad redemptionem eorum. ${ }^{41}$ Contingit autem multoties, quod taliter obligati et maxime pueri uel puelle ${ }^{42}$ fiunt postmodum sarraceni et si postea repetuntur ${ }^{43}$ non redduntur.

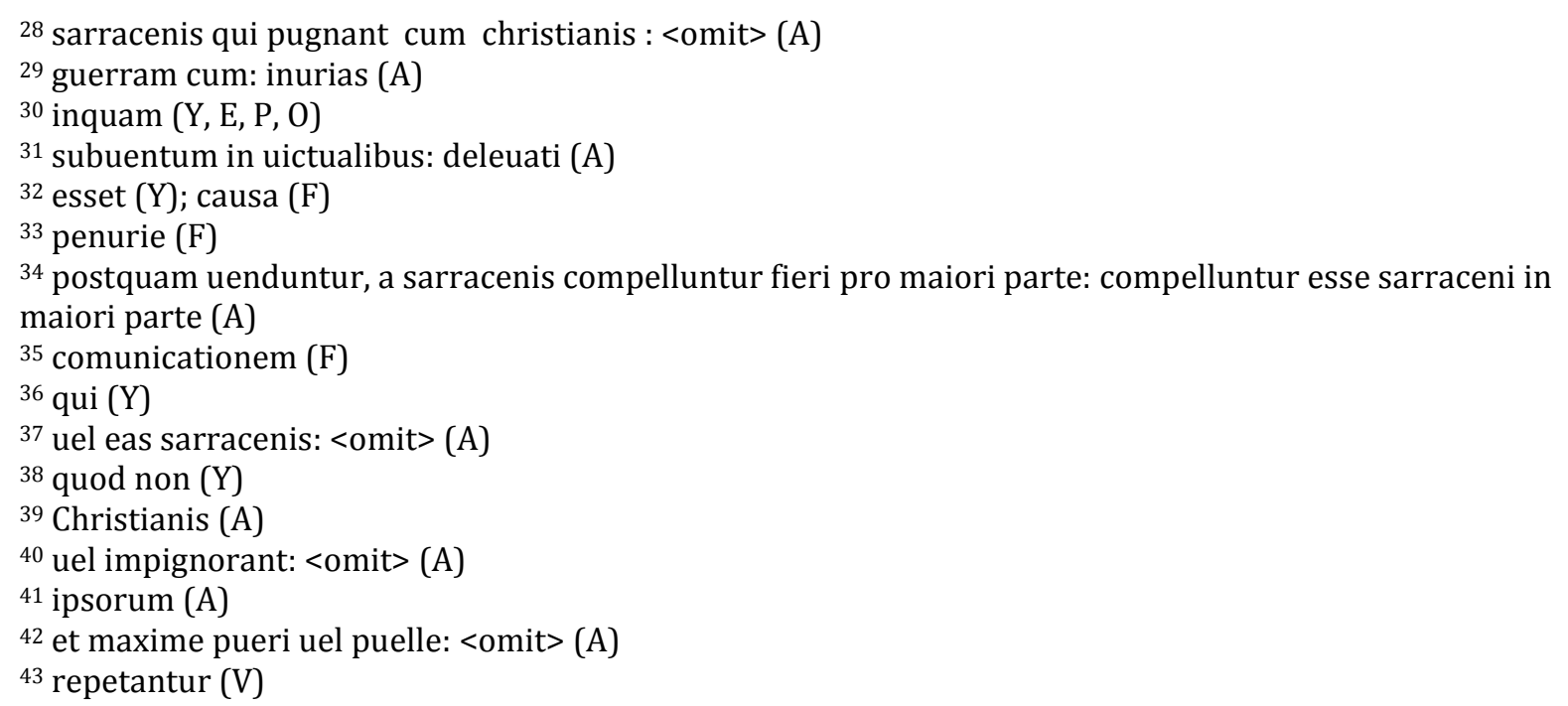


Respondemus: similiter.

9. Item, quidam captiui christiani siue christiane conuersantur cum sarracenis habentibus infantulos ${ }^{44}$. Querimus utrum possimus talibus christianis ${ }^{45}$ ut bapticent consulere furtiue eos infantulos, sine consensu et ${ }^{46}$ uoluntate siue conscientia parentum, sub spe quod taliter baptizati $\mathrm{si}^{47}$ decedant antequam atingant annos discretionis ${ }^{48}$ saluabuntur, licet presumatur de talibus uel de taliter ${ }^{49}$ baptizatis, quod cum annos discretionis attingerint, displicebit eis fuisse baptizatos, si eis constiterit de baptismo suscepto.

Respondemus: baptizentur tales.

10. Item, sunt quidam qui fuerunt christiani et postmodum facti sunt sarraceni. Alii in minori etate, alii iam adulti: alii ex ipsis sunt liberi, alii captiui. ${ }^{50}$ Cum omnes ${ }^{51}$ errent contra articulos fidei negantes christum ${ }^{52}$ esse deum et dei filium, negantes ${ }^{53}$ etiam incarnationem ipsius et passionem, querimus si cum talibus possint communicare ${ }^{54}$ patres uel matres eorum, uel huius coniuncte persone uel quilibet alius indifferenter, et cum illis maxime quia facti sunt sarraceni ignorantes articulos fidei, uel quia fuerunt $\mathrm{ab}$ infantia captiuati ${ }^{55}$ uel alias quacumque neglegentia mediante cum predicte persone uix uideatur nobis quod ${ }^{56}$ possint abstinere commode ${ }^{57}$ a communione predictorum, tum propter carnalitatem qua eos diligunt utpote ${ }^{58}$ filios, tunc quia recipiunt ab eis uictualia.

Respondemus: possunt ei communicare ${ }^{59}$ causa correctionis uel necessitatis et $^{60}$ recipere $a b$ eis uictualia in necessitate ${ }^{61}$ et maxime parentes ${ }^{62}$ uel alie coniuncte persone.

11. Item, si alter coniugum labatur in heresym, utrum possit communicare uel cohabitare ei alter qui remanet in fide.

Respondemus: potest, si uult, dummodo sine contumelia creatoris, etsi non pertrahit eum ${ }^{63}$ ad mortalem. Sed tutius est ut, auctoritate ${ }^{64}$ ecclesie, a tali cohabitatione recedat.

\footnotetext{
44 infamulos (E)

$45<$ omit> (A)

46 consensu et $<$ omit $>(\mathrm{O}, \mathrm{Y})$

47 <omit> Y

48 discretos (Y)

${ }^{49}$ uel de taliter <omit> (A)

50 alii captiui <omit $>$ (A)

$51<$ omit> (A)

$52<$ omit> (A)

53 negantes ... passionem <omit $>$ (F)

${ }^{54}$ cohabitare (A)

55 captiui $(A, 0)$

56 uideatur nobis quod < omit $>$ (A)

57 domo (A)

58 ut potes $(\mathrm{E})$

${ }^{59}$ cohabitare (A)

60 et ... uicutalia <omit $>(P)$

61 in necessitate <omit $>$ (A)

62 pater et mater $(\mathrm{F})$

63 Eum: <omit> (A, V)

64 occasione (A)
} 
1265. Item, querimus qualiter procedemus cum fratribus spiritualibus matrimonio copulatis ante aduentum nostrum in regno de tunici66. Timemus enim ex separatione talium uel magnum scandalum uel apostasie secuturum periculum in quod ipsi ${ }^{67}$ facile dilabantur 68 , maxime cum clerici sub quorum cura erant tunc cum contraherent, super hoc ab ipsis consulti ${ }^{6}$, contractum huius non dissuaderent nec interdicerent, immo potius ${ }^{70}$ auctoritatem contractam uel contractui preberent inter tales in facie ecclesie matrimonium ${ }^{71}$ sollemniter celebrando.

Respondemus: si potest fieri absque scandalo et periculo apostasie, separentur ${ }^{72}$ tales: alioquin secreto ${ }^{73}$ in foro penitentiali in secreto ${ }^{74}$ dispensetur cum contractis, et districte ac publice inhibeatur ne de cetero similia fiant.

13. Item, aromes ${ }^{75}$ quorum curam gerimus, sunt multi proni ${ }^{76}$ et faciles ad uouendum et ad iurandum quedam licita77, puta non bibere uinum et huius. Que postmodum, sine magna difficultate non possunt obseruare: immo ipsi auctoritate propria infringunt uota et iuramenta sua, etiam si nos non dispensemus cum eis. Unde indigeremus, si fieri posset, ut possemus cum talibus aliquatenus ${ }^{78}$ dispensare.

Respondemus: dispensetur cum talibus ${ }^{79}$ per commutationem penitentie et inhibantur ne sint proni ad uota similia emittenda. ${ }^{80}$

14. Item, qualiter procedemus, cum hiis qui accommodant denarios uel res alias ad fortunam maris et utrum hec sit usura, cum plus accipiant quam dent.

Respondemus: procedatur secundum nouam decretalem Nauiganti.

1581. Item, de dispensatione ${ }^{82}$ cum hiis qui, post crucis signationem, uenerunt in terram sarracenorum et post modum, multis de causis impediti, utpote ${ }^{83}$ quia duxerunt uxores ibi ${ }^{84}$ tacito quod essent crucesignati, uel quia non audent recedere propter metum sarracenorum.

Respondemus: iniungatur alia penitentia crucesignatis ${ }^{85}$ qui propter infirmitatem, paupertatem uel timorem sarracenorum uotum implere non possunt; alii grauibus occupationibus detenti, non implicent se aliis, sed illis expeditis prosequantur uotum.

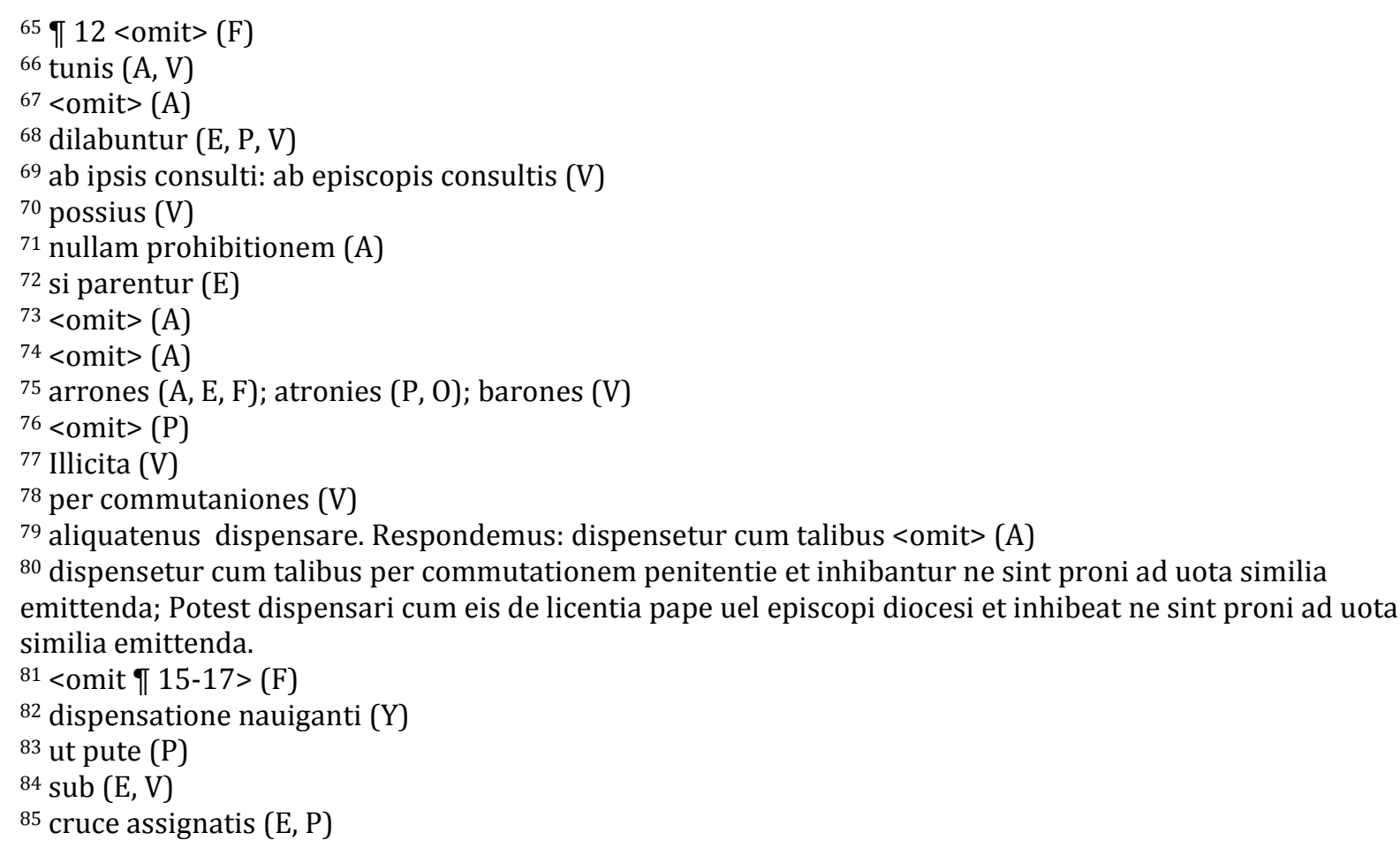


16. Item, utrum liceat nobis celebrare missam ante auroram propter timorem in $^{86}$ quo sunt isti quorum curam gerimus, et maxime in diebus paschalibus, in quibus nec aliter nobis sufficeret commode tempus ad celebrandum diuina et ad populum communicandum.

Respondemus: potest aliquando ${ }^{87}$ fieri propter metum ${ }^{88}$ sarracenorum; alias non nisi in nocte Natiuitatis ${ }^{89}$.

17. Item, utrum liceat celebrare illi qui post hesternam ${ }^{90}$ comestionem usque $^{91}$ ad horam celebrationis non dormiuit, uel quia non potuit, uel propter occupationes licitas.

Respondemus: potest utique, si celebraturus credat cibum iam digestum.

18. Item, utrum liecat celebrare cum $^{92}$ uestimentis ${ }^{93}$ et maxime corporalibus non benedictis, causa necessitatis.

Respondemus: non licet.

19. Item, utrum liceat nobis ${ }^{94}$ consecrare chrisma et oleum infirmorum et cathecumenorum cum uno socio tantum uel duobus, cum plures habere non potuerimus.

Respondemus: licet Episcopo.

2095. Item, cum ex indulgentia domini Honorii, nobis liceat excommunicatos illos absoluere, qui ad sedem apostolicam commode non possunt accedere causa absolutionis, querimus quid notare uelit illud commode ${ }^{96}$, et utrum possimus excommunicatos illos absoluere qui non tenentur ire ad curiam, prius prestito iuramento quod quam citius poterunt mandatum ${ }^{97}$ ecclesiasticum adimplebunt in suorum presentia prelatorum, et utrum teneat absolutio illorum, quam bona conscientia usque huc fecimus circa huius; sin autem quid nos oporteat facere.

Respondemus: intellegitur non posse accedere commode, ubi iustum impedimentum est, puta infirmitatis, senectutis ${ }^{98}$ multe ${ }^{99}$ paupertatis et similia ${ }^{100}$, que melius dispensantis prouidentia, quam uerbi expressione, possunt comprehendi. ${ }^{101}$ Illos autem qui non tenentur ire ad curiam, sed a suis praelatis possunt absolui, potestis absoluere. Quia dominus Papa concedit hoc uobis, dum tamen ${ }^{102}$ sint commorantes. Absolutio quoque facta a uobis huc usque de talibus, uel ab illis fratribus qui fuerunt ${ }^{103}$

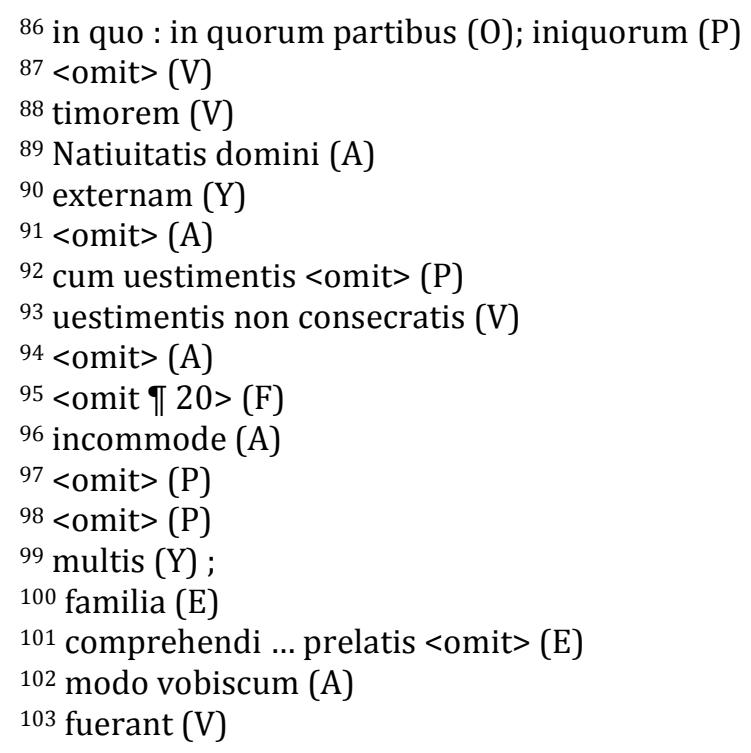


in regno marochitano, ${ }^{104}$ non tenet nisi fuissent subiecti uostri uel ${ }^{105}$ ipsorum, aut uobis uel eis fuisset indultum; unde taliter absoluti remittantur ${ }^{106}$ ad suos prelatos, uel illos quibus absoluendi tales fuerit indulta potestas.

21. Item, de hiis ${ }^{107}$ qui furantur decimas sarracenis utrum eisdem teneantur restituere. ${ }^{108}$

Respondemus: tenentur restituere. ${ }^{109}$

22. Similiter utrum teneantur de usuris contractis ${ }^{110}$ restituere sibi.

Respondemus: tenentur. ${ }^{111}$

23. Item, super quibusdam aliis similiter articulis ${ }^{112}$ dubitamus. Primo, utrum portantes ferrum una terra sarracenorum in aliam sint excommunicati.

Respondemus: non, nisi fiat in dispendio terre sancte, uel alias contra christianos.

24. Item, et illi qui apportant sarracenos cum armis suis.

Respondemus ut supra.

25.113 Item, quidam apportant ligna paruicula. Dubitamus ${ }^{114}$ utrum de ${ }^{115}$ hiis lignaminibus intellegatur canon.

Respondemus: si ad naues uel ${ }^{116}$ ad machinas ad impugnandum christianos uel in dispendium terre sancte, sunt excommunicati.

26. Item, sunt quidam qui portant stuppam et canapum, picem et funes et similia. Respondemus ut supra, proximo.

27117. Item, cultellos ${ }^{118}$ paruissimos et clauos minutissimos, et isti uel uendunt uel dant, utrum sint excommunicati.

Respondemus ut supra.

28. Item, sunt quidam alii qui capiunt clericos latrones uerberando cum prelati non sint utrum ${ }^{119}$ sint excommunicati. Et si sunt, utrum possimus eos absoluere.

Respondemus $^{120}$ : sunt ${ }^{121}$, nisi ${ }^{122}$ de mandato prelatorum ${ }^{123}$ hoc faciant, et id rebellio exigat talium clericorum. Potestis autem eos absoluere si sit uobis indultum, alias non.

\footnotetext{
104 maior bono (E); maioricano (V); maiorichano (A)

105 uostri uel : <omit> (V)

106 remittentur $(\mathrm{V})$

107 illis (A)

108 eisdem teneantur restituere: teneantur restituere sibi $(\mathrm{V})$; restituere: reddere $(\mathrm{A})$

${ }^{109}$ Respondemus: tenentur restituere : <omit> (A, V)

110 certis $(0)$

${ }^{111}$ restituere eis tenentur $(0, P, V)$

112 capitulis uel articulis (F)

$113<$ omit $\uparrow 25-27>(V)$

114 Dubitamus <omit $>(\mathrm{Y})$

115 de ... canon $<$ omit $>$ (E)

116 uel ad machinas <omit $>$ (F)

$117<$ omit ๆ 27> (A)

118 cultellus (Y) ; cullilos (E)

119 utrum sint <omit> (Y)

$120<$ omit $>(0)$
} 
29. Item, sunt alii qui uolunt permutare ${ }^{124}$ cultellum cum arcu uel e conuerso, uel aliquod consimilem ${ }^{125}$, utrum qui fecerint sint excommunicati.

Respondemus: non nisi ${ }^{126}$ fiat in dispendium terre sancte, uel ad impugnandum christianos ${ }^{127}$.

30128. Item, qui intellegantur commorantes: utrum qui per annum uel dimidium moram fecerint intellegantur commorantes 129

Respondemus: qui proponit de cetero ibi morari, maxime si iam morati sunt per annum.

31. Item, cum contineatur in indulgentia quod possimus absoluere in necessitatis articulo $^{130}$ dubitamus ${ }^{131}$ de quo articulo intellegatur pro qualibet ${ }^{132}$ febre uel fluxu.

Respondemus: ubi timetur uel timeri potest periculum mortis.

32. Item, quid faciendum sit de clericis negotiatoribus, cum scandalum generent?

Respondemus: compescantur ${ }^{133}$ a prelatis suis per censuram ecclesiasticam, uel aliam penam canonicam.

33. Item, sunt quidam qui apportant prohibita ignorantes esse prohibita, utrum sint excommunicati, et si sunt, utrum possimus eos absoluere.

Respondemus: cum in utroque concilio prohibita sint et publicata non licet ignorare; tamen absoluantur ad minus ad cautelam.

34. Item, quid de illis faciendum est qui portant prohibita ${ }^{134}$, et quam cito sciunt illa esse prohibita, reportant et nolunt uendere sarracenis.

Respondemus: non sunt excommunicati.

35135. Similiter sunt quidam qui apportant res prohibitas et uendiderunt et partes, et alia superest ad uendendum. Si tales contingat absolui aliqua necessitate, cuiusmodi consilium dabitur eis de alia parte.

Respondemus: reportent eam.

36. Item sunt qui petunt absolutionem causa maris. Utrum possimus eos absoluare.

Respondemus : Non.

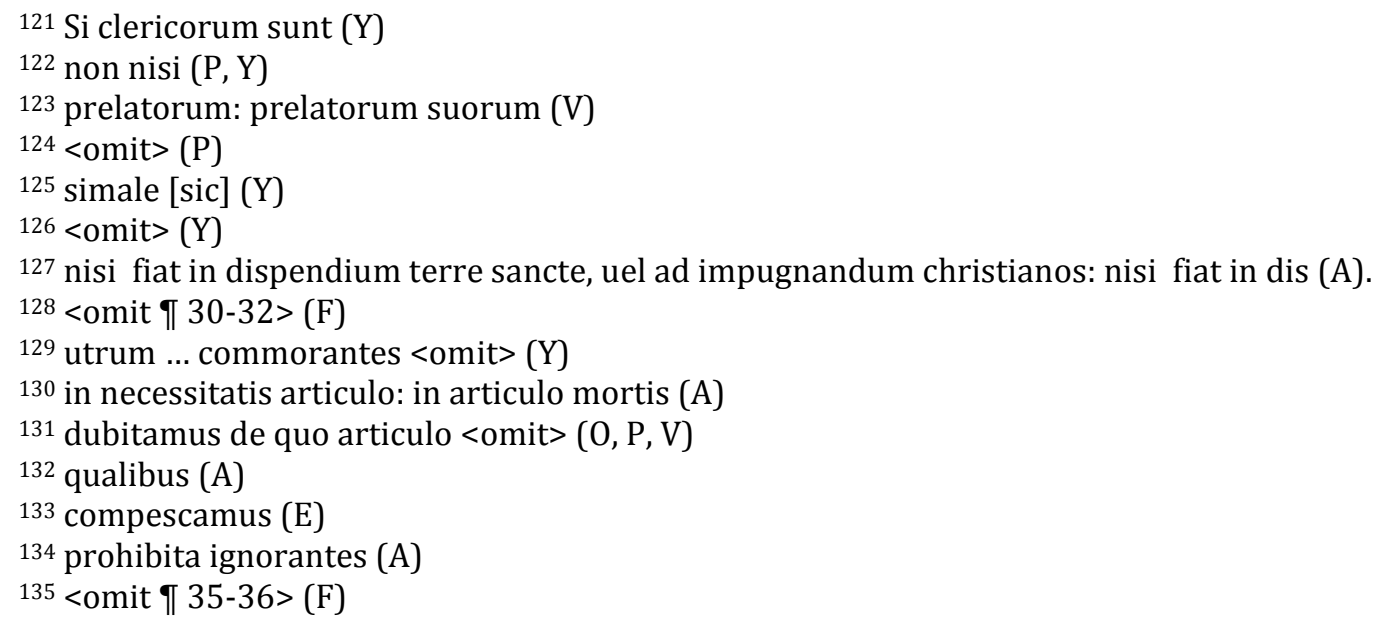


37. Item sunt alii qui dant uel uendunt prohibita sarracenis ignorantes quod propter hoc sint excommunicati, et quam cito sciunt recuperant. Utrum tales sint excommunicati; et si sunt, utrum possint ${ }^{136}$ absolui.

Respondemus: sunt excommunicati ${ }^{137}$ et absoluantur .

38138. Item ${ }^{139}$ utrum teneamur uitare excommunicatos ante denuntiationem, cum quidam sint qui non asserere uideantur, et nobis, de iure, contrarium uideatur.

Respondemus: tenemini, secundum distinctionem decretalis Cum desideres ${ }^{140}$.

39. Item, quomodo intellegatur illud quod dicitur de sarracenis habentibus guerram cum christianis, utrum si cum uno rege uel ciuitate, uel cum ${ }^{141}$ ecclesia, uel qualiter intellegatur.

Respondemus: de quolibet christiano.

40. Item aliquis est debitis obligatus pro uictu suo uel aliis, et nichil habet, nec aliquid lucrari potest. Necessitate tali compulsus intrat nauem aliquam pro marinario ut possit lucrari unde possit uiuere et debita persoluere ${ }^{142}$; et nauis illa portat ${ }^{143}$ res prohibitas in terram sarracenorum, et aliam non potest inuenire ubi possit lucrari. Utrum iste talis sit excommunicatus, precipue cum ipse plus habeat de lucro mercedis quam expendit uel debeat, saltem ${ }^{144}$.vi. ${ }^{145}$ denarios, uel circa illud, uel plus. ${ }^{146}$

Sunt excommunicati quia communicant in crimine illis qui mittunt uel portant, dando eis auxilium et cooperationem, licet pro mercede. Sed in satisfactione pecunie uel penitentie ${ }^{147}$ mitius agatis cum eis, prout uestra discretio uiderit expedire.

Datum Perusii XIIII kalendas februarii, pontificatus domini Gregorii anno VIII. ${ }^{148}$

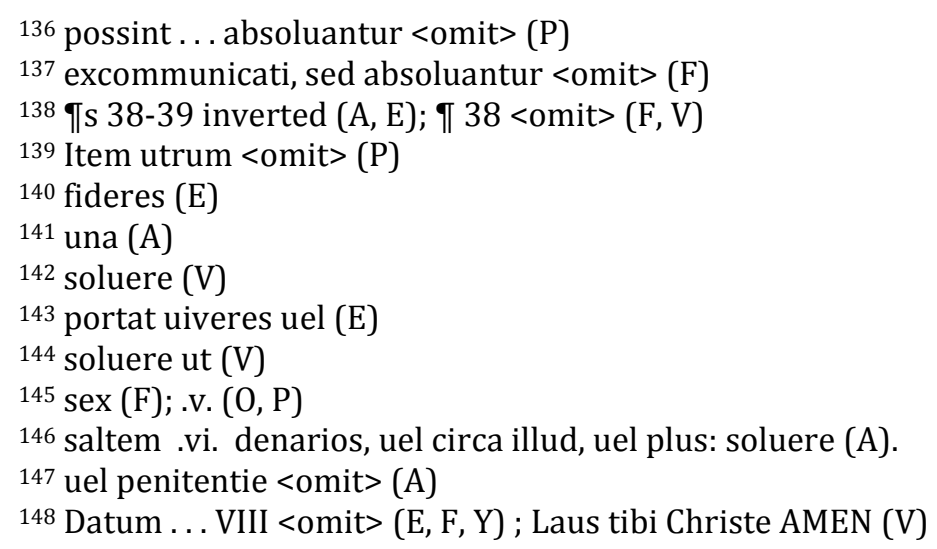




\begin{abstract}
Ramon de Penyafort
Responses to questions concerning relations between Christians and Saracens
\end{abstract} (19 January 1235)

Translation by John Tolan

Brother Raymond, confessor of the Lord Pope, to the beloved brothers in Christ, J., prior of the order of Preachers and G., minister of the order of Minor Brothers residing in the kingdom of Tunis, greetings in the name of God.

You have asked to be instructed by the Holy See what you should do in regard to the following items. Your questions, which are transcribed below, were read before the Lord Pope. His responses, which he gave after deliberation concerning each item, I faithfully disposed, in accord with his special mandate; [they are] binding, so that in the confessional you may intrepidly judge according to their tenor.

1. Since by the order of Lord Innocent, those who sell ships or take arms or iron or provide any aid to Saracens are excommunicated, what of those Genoans who sell ships, particularly old ones, to the Saracens, saying that this was not prohibited to them by their own prelates?

We respond: those who take ships or wood for galleys, arms or iron are excommunicated, whenever they do it, and this by both councils. For those who trade these things to the detriment of the Holy Land are excommunicated by the last council [Lateran IV]; while if these things serve to fight Christians, they are excommunicated by the first Lateran council [in fact, Lateran III].

2. In the same way, Spaniards give or sell spurs, bits and saddles; we wonder if these things should be considered as arms.

We respond: if they do this in time of war, they are excommunicated.

3. Also, if the category of aid includes foodstuffs, what of Spaniards who sell goats and sheep, etc.; Pisans and Genoans wine, wheat, beans, chestnuts, hazelnuts, etc. to the Saracens, saying that such sales were not prohibited to them by their prelates; hence this leads us into doubt as to whether all the aforementioned people are excommunicated.

We respond: those who sell such things are indeed [excommunicated] if they do this in wartime and sell such things to Saracens who are fighting against Christians; and this is according to the first Lateran Council [Lateran III].

4. Also, certain Christian merchants charge their ships with grain and other food in Saracen regions which are fertile, and take them to other regions of Saracens who are at war with Christians. These Saracens would perhaps in the end be defeated, either through lack of rations or through war, if it these merchants did not aid them in this way by bringing them food. Since this supplying of food is of great aid to the Saracens, whether or not they are at war, we ask whether such merchants are excommunicated.

We respond: they are indeed, as according to previous response [§3].

5. Also, whether he who takes arms (i.e., a sword, a lance, a knife, etc.) into the lands of the Saracens, not intending to sell it but for his self-defense and who later, out of financial need, sells it to Saracen, is excommunicated.

We respond: they are excommunicated. 
6. Also, whether those who sell Christians to Saracens are excommunicated, especially since most of those who are sold are forced to become Saracens.

We respond: they are not excommunicated, but they sin mortally.

7. Also, some capture Jews or Saracens, especially women, and take them into the lands of the Saracens, by force or not, and make them declare to the Saracens that they are Christians; they then sell them, as Christians, to the Saracens. We ask whether such people are excommunicated for the insult they proffer to the Christian name through this kind of sale.

We respond: they are not excommunicated, but they sin mortally.

8. Also, whether are excommunicated those Christians, knights or others, who, having commerce with Saracens, pawn or mortgage to Saracens men or women from among their own servants, compelled by necessity. In particular, in those numerous cases when they know that they will not be able to redeem those whom they pawn. It often occurs that those who are pawned in this way, especially the boys and girls, later become Saracens - and if they later are reclaimed, they are not returned. ${ }^{149}$

We respond in the same way.

9. Also, certain Christian captives, men or women, live with Saracens who have infant children. We ask whether we can advise such Christians to secretly baptize these infants, without the knowledge, will or consent of their parents, in the hope that, should some of those thus baptized die before they reach the age of discretion, they may be saved. For we may presume that those who have been so baptized, once they reach the age of discretion, would be displeased if they were to learn that they had been baptized in this way.

We respond: let them be baptized.

10. Also, there are some who were once Christians and then became Saracens, some while they were minors, others as adults; some of them are free, others captives. Since they all err against the articles of the faith, denying that Christ is God and Son of God, since they deny his Incarnation and Passion, we ask if the fathers, mothers, or other relatives of such people, or other people may communicate with them. Many of these people, when they converted, were ignorant of the articles of the faith; some were taken captive as infants; others converted due to a certain negligence. It seems to us that they cannot easily abstain from frequenting the above-mentioned people, either because they love them according to the flesh, as their children, or because they receive food from them.

We respond: they may communicate with them, either in order to correct them or out of necessity, and may receive food from them when they are in need, especially their relatives and other people connected with them.

11. Also, if one person in a married couple sinks into heresy, whether the one who remains in the faith may communicate or cohabit with him.

We respond: he can, if he wishes, as long as it is without insult to the Creator, and if it does not lead him into mortal sin. Yet, by the authority of the Church, it is safer that he refrain from such cohabitation.

149 This presumably refers to negotiations to free captives, either by exchange or for ransom: the idea being that those who have converted to Islam are not given over to the Christians. 
12. Also, we ask how to proceed in the case of spiritual brothers who had bound themselves in matrimony before our arrival in the Kingdom of Tunis. For we fear lest by separating them, the result would be either a great scandal or the danger of apostasy, into which they could easily slide. This is particularly the case since the priests under whose care they were when they contracted [marriage], when consulted about this, did not dissuade them or prohibit them from doing so; on the contrary they granted their authority to the contract, solemnly celebrating the wedding in the face of the Church.

We respond: if it can be done without scandal or risk of apostasy, separate such couples. Otherwise, secretly in the confessional, grant dispensation to those who have contracted such marriages, and strictly and publicly prevent others from doing similar things.

13. Also, the Aromes, ${ }^{150}$ whose care we have, are quite prone to swearing oaths, on legitimate things, for example not to drink wine or things of the sort. They then find themselves unable to respect these oaths, except through great exertion on their part. They then break their vows by their own authority, unless we absolve them of their vows. Hence we ask if it is possible that we might on some occasions dispense them from such oaths.

We respond: they may be dispensed from such oaths by commutation of penance. And let them not be prone to make such oaths.

14. Also, how should we proceed with those who lend money or other things, entrusting them to the risks of sea travel; should this be considered usury when they take more than they give?

We respond: the new Decretal Naviganti ${ }^{151}$ should be followed.

15. Also, concerning the dispensation of those who, after having been marked with the sign of the cross, come to Saracen lands and later, for many and various reasons, are prevented [from fulfilling their crusade oath], either because they marry there without revealing that they are marked with the cross, or because they do not dare return through fear of the Saracens.

We respond: another type penance shall be imposed on those who are marked with the cross who, on account of illness, poverty or fear, are unable to fulfill their vow. Others, who are detained by important occupations should not take on new occupations, but, once their other duties have been performed, should fulfill their vows.

16. Also, whether it is permitted to us to celebrate mass before dawn, on account of the fear of those whose care we have, particularly in the Easter season, during which there is not enough time for us to celebrate the divine offices and to give communion to the people.

We respond: it can be done sometimes, on account of fear of the Saracens; otherwise not, except on Christmas Eve.

17. Also, whether it is permitted for those to celebrate the mass if they have not slept between their meal the previous day and the hour of the mass, either because they were not able to, or on account of licit occupations.

150 On the Aromes (elsewhere Aramos, Arrones, Atronii or Atronies), see introduction, above.

${ }^{151}$ X V, 19, 19. 
We respond: it may be done, if he who celebrates the mass believes that his food has been digested.

18. Also, whether it is permitted to celebrate with unblessed vestments and vessels when necessary.

We respond: it is not permitted.

19. Also, whether it is permitted for us to consecrate chrism and oil for the sick and for catechumens with only one or two companions, since we cannot have more.

We respond: it is permitted for the Bishop to do this.

20. Also, since through the indulgence of lord [Pope] Honorius [III], it is permitted to us to absolve excommunicates who are not able easily to go to the Apostolic See to be absolved, we ask what, in this case, "easily" means, and whether we can absolve excommunicates who are not required to go to the Curia, if they first vow that they as soon as they can they will fulfill the Church's orders in the presence of their prelates, and that in order for their absolution to be maintained. This is what we have done, in good conscience, up until now. Otherwise, how should we proceed?

We respond: it should be understood that those who cannot "easily" go are those who have a true impediment, such as illness, old age, great poverty, etc.: this can be better judged by the prudence of he who gives the dispensation than by verbal expression.

Those who are not required to go to the curia, but rather to be absolved by their prelates, you may absolve, because the Lord Pope conceded this to you, as long as they are residents. The absolution performed by you until now concerning such persons, or by those friars who were in the Moroccan Kingdom, does not apply for they were not subject to you or to them, nor were you or they granted an indult. Hence those thus absolved should be sent back to their prelates or to those to whom power of absolving these people has been granted.

21. Also, if those who steal the tithes of the Saracens are obliged to return them. We respond: they are obliged to return them.

22. Similarly, whether they are required to pay debts contracted through usury. We respond: they are required to restitute them.

23. Also, we have doubts concerning other similar items. First, whether those who take iron from one Saracen land into another are excommunicated.

We respond: No, unless this is done to the detriment of the Holy Land, or in other ways against Christians.

24. Also, those who transport armed Saracens.

We respond as above.

25. Also, some transport small pieces of wood. We doubt whether this should be understood as wood prohibited by the canon.

We respond: if it is used for ships or war machines for fighting Christians or to the detriment of the Holy Land, they are excommunicated.

26. Also, some transport flax, hemp and pitch, and ropes and similar things. 
We respond as directly above.

27. Also, tiny knives and miniscule nails-are those who sell them excommunicated? We respond as above.

28. Also, some people who are not prelates capture thieves who are clerics and whip them. Are these people excommunicated? If so, may we absolve them?

We respond: they are [excommunicated], unless they do this at the orders of a prelate, and the rebellion of such clerics makes this necessary. You may however absolve them if you have been granted an indult to do so, otherwise no.

29. Also, there are some who wish to exchange a knife for a bow or the opposite, or something similar, whether those who do this are excommunicated.

We respond: no, unless they do it to the detriment of the Holy Land, or for fighting against Christians.

30. Also, who should be considered to be residents: those who stay for a year? For half a year?

We respond: those who intend on staying there, especially if they have already stayed for a year.

31. Also, since the indulgence allows us to perform absolutions in case of necessity, we wonder what this means, if it includes any fever or infection.

We respond: where death is feared or can be feared.

32. Also, what to do about clerics who are merchants, since they cause scandal?

We respond: they shall be restrained by their prelates through ecclesiastical censure or through another canonical punishment.

33. Also, they are some who transport prohibited items without knowing that they are prohibited. Are they excommunicated, and if yes, may we absolve them?

We respond: since these things are publically prohibited by both councils, it is not permitted to ignore this. But they may be absolved with lighter penance.

34. Also, what about those who transport prohibited items, and as soon as they learn that they are prohibited, take them back and refuse to sell them to the Saracens.

We respond: they are not excommunicated.

35. Similarly, there are some who bring prohibited things and sell part of them, and part remains to be sold. If it so happens that they are absolved through some compulsion, what advice can we give them about the other part?

We respond: they should return it.

36. Similarly some petition for absolution by reason of being a seafaring merchant. May we absolve them?

We respond: no.

37. Also, there are others who give or sell prohibited items to Saracens, not knowing that they are excommunicated for this, and as soon as they know it, they retrieve the things. Are such people excommunicated? If so, can they be absolved? 
We respond: they are excommunicated, but they shall be absolved.

38. Also, whether we are obliged to avoid excommunicated people before they have been denounced, as some claim; to us, according to law, it seems to be the contrary.

We respond: you indeed are required [to avoid them], as according to the distinction of the Decretal Cum desideres. ${ }^{152}$

39. Also, how should we understand that which is said about Saracens at war with Christians: does it mean with one king or city, or with the Church, or how should it be understood?

We respond: with any Christian.

40. Furthermore, someone is obliged by debt, for his sustenance or for other reasons, and he has nothing, nor does he have any means to earn money. Compelled by such necessity, he boards a ship as a sailor so that he can earn a living and pay his debts; and this ship carries prohibited items into Saracen lands; and he can find no other way to earn a wage. Is such a man excommunicated, in particular since he has, as profit or wage beyond that which he spends and owes, perhaps five denarii, more or less.

We respond: they are excommunicated, for they participate in the crime with those who send or carry, giving them aid and cooperation, even if only for a wage. But in the granting of penance act more mildly with them, as your discretion will see fit to expedite.

Given in Perugia on the $14^{\text {th }}$ of the Calends of February, in the eighth year of the pontificate of Lord Gregory. 


\title{
Raymond de Penyafort \\ Réponses aux questions concernant les relations entre chrétiens et Sarrasins (19 janvier 1235)
}

\author{
Traduction de Laurence Foschia
}

Sur certaines questions douteuses

Frère Raymond, confesseur de sa Sainteté le pape, à ses bienheureux frères en Christ, J., prieur de l'ordre des prêcheurs et G., ministre de l'ordre des Frères Mineurs résidant dans le royaume de Tunis, salutations au nom de Dieu.

Vous avez demandé à être informés par le Saint Siège de ce qu'il vous convient de faire dans les matières qui suivent. Vos questions transcrites ci-dessous ont été lues devant sa Sainteté le pape. Les réponses qu'il donna après avoir délibéré sur chacun des points, je les ai fidèlement rapportées, conformément au mandat spécial qu'il m'a donné, après les avoir regroupées afin que ce soit sans crainte que vous rendiez vos jugements dans le confessionnal en fonction de leur teneur.

1. Puisque, sur ordre de sa Sainteté Innocent, ceux qui vendent des navires, transportent des armes ou du fer ou fournissent de l'aide aux Sarrasins sont excommuniés, que faut-il faire de ces Génois qui vendent des navires, en particulier des vieux bateaux, en disant que cela ne leur a pas été interdit par leurs propres prélats?

Nous répondons : ceux qui s'emparent de navires ou du bois des galères, d'armes ou de fer sont excommuniés, quel que soit le moment où ils le font, par les deux conciles. Car ceux qui font ce genre de commerce au détriment de la Terre Sainte sont excommuniés par le dernier concile [Latran IV] ; mais si le commerce de ces biens est destiné à combattre les chrétiens, ils sont excommuniés par le premier concile de Latran [en réalité Latran III].

2. De la même façon, les Espagnols donnent ou vendent des éperons, des mors et des selles ; nous nous demandons si on doit les considérer comme des armes.

Nous répondons : s'ils se livrent à cela en temps de guerre, ils sont excommuniés.

3. Également, si par "aide", il faut entendre aussi la nourriture, que faire des Espagnols qui vendent des chèvres et des moutons, etc., ou des Pisans et de Génois qui vendent du blé, du vin, des haricots, des châtaignes, des noisettes, etc. aux Sarrasins en disant que vendre cela ne leur est pas interdit par leurs prélats, d'où l'incertitude dans laquelle nous nous trouvons : toutes les personnes mentionnées précédemment sont-elles excommuniées?

Nous répondons : ceux qui vendent cela le sont en effet [excommuniés] s'ils le font en temps de guerre et s'ils vendent ces biens aux Sarrasins qui se battent contre des chrétiens et ce, conformément au premier concile de Latran [Latran III].

4. Également, certains marchands chrétiens chargent leurs navires de grain et d'autres victuailles dans les régions sarrasines qui sont fertiles et les emportent dans les autres régions sarrasines qui sont en guerre avec les chrétiens. Ces Sarrasins pourraient peutêtre être vaincus à la fin soit à cause du manque de ravitaillement soit à cause de la guerre si ces marchands ne les aidaient pas de cette façon en leur apportant de la 
nourriture. Puisque ce ravitaillement en nourriture est d'une grande aide pour les Sarrasins, qu'ils soient ou non en guerre, nous demandons si ces marchands sont excommuniés.

Nous répondons : ils le sont en effet, conformément à notre réponse précédente.

5. Également, celui qui apporte des armes (c'est-à-dire une épée, une lance, un couteau, etc.) dans les contrées sarrasines non dans l'intention de les vendre mais pour sa propre défense et qui, après, se trouvant dans le besoin, les vend à un Sarrasin est-il excommunié ?

Nous répondons : ils sont excommuniés.

6. Également, ceux qui vendent des chrétiens à des Sarrasins sont-ils excommuniés, surtout étant donné que la plupart de ceux qui sont vendus sont forcés à devenir sarrasins? mortel.

Nous répondons : ils ne sont pas excommuniés mais ils commettent un péché

7. Également, certains capturent des juifs ou des Sarrasins, surtout des femmes, et les emmènent dans les pays des Sarrasins, de force, et les obligent à déclarer aux Sarrasins qu'ils sont chrétiens ; ensuite ils les vendent, en tant que chrétiens, aux Sarrasins. Nous demandons si ces individus sont excommuniés pour l'insulte qu'ils font au nom chrétien en pratiquant ce genre de commerce.

Nous répondons : ils ne sont pas excommuniés mais ils commettent un péché mortel.

8. Également, est-ce que sont excommuniés ces chrétiens, chevaliers ou autres, qui, ayant des relations commerciales avec les Sarrasins, poussés par la nécessité, mettent en gage ou hypothèquent, auprès des Sarrasins des hommes et des femmes qui font partie de leurs propres domestiques? En particulier, souvent ceux qui savent qu'ils ne pourront pas racheter ceux qu'ils ont mis en gage. Il arrive souvent que ceux qui ont été mis en gage de cette façon, surtout les garçons et les filles, deviennent plus tard sarrasins - et si par la suite on les revendique, ils ne sont pas rendus. ${ }^{153}$

Nous répondons de la même façon.

9. Également, certains prisonniers chrétiens, hommes ou femmes, vivent avec des Sarrasins qui ont des enfants en bas âge. Nous demandons si nous pouvons conseiller à ce genre de chrétiens de baptiser en secret ces enfants sans que les parents le sachent, le veulent ou l'approuvent, dans l'espoir que si certains de ces baptisés mouraient avant d'avoir atteint l'âge de raison ils puissent être sauvés. Car nous pouvons supposer que ceux qui ont été baptisés de cette façon, une fois parvenus à l'âge de raison, seraient mécontents s'ils devaient apprendre qu'ils ont été baptisés de la sorte.

Nous répondons : qu'ils soient baptisés.

10. Également, il y a des gens qui jadis étaient chrétiens et qui sont ensuite devenus païens, certains lorsqu'ils étaient mineurs, d'autres à l'âge adulte ; certains d'entre eux sont libres, d'autres prisonniers. Comme tous pèchent contre articles de la foi, niant que Christ est Dieu et Fils de Dieu, puisqu'ils nient son Incarnation et sa Passion, nous demandons si les pères, mères ou autres parents de ces gens ou d'autres personnes

${ }^{153}$ Dans les négociations pour le rachat ou échange des prisonniers, les musulmans refusaient de redonner aux chrétiens les captifs qui s'étaient convertis à l'islam. 
peuvent entrer en contact avec eux. Beaucoup d'entre eux, lorsqu'ils se sont convertis, ignoraient les articles de la foi ; certains furent faits prisonniers dans leur prime enfance ; d'autres se sont convertis pour ainsi dire par négligence. À ce qu'il nous semble, ils ne sauraient éviter de fréquenter les personnes mentionnées ci-dessus, soit parce qu'ils les aiment en raison de liens familiaux, comme lorsqu'il s'agit de leurs enfants, ou parce celles-ci leur fournissent de la nourriture.

Nous répondons : ils peuvent entrer en contact avec eux, soit pour les corriger ou par nécessité, et peuvent recevoir d'eux de la nourriture lorsqu'ils sont dans le besoin, surtout quand il s'agit de leurs parents ou de personnes ayant un lien avec eux.

11. Également, si l'un des partenaires, au sein d'un couple marié, tombe dans l'hérésie, celui qui demeure dans la foi peut-il communiquer ou vivre avec lui ?

Nous répondons : il le peut, s'il le souhaite, aussi longtemps qu'aucune insulte n'est proférée à l'égard du Créateur et si cela ne le conduit pas à commettre un péché mortel. Cependant, d'après l'autorité de l'Église, il est plus sûr pour lui de s'abstenir de ce genre de cohabitation.

12. Également, nous demandons comment nous y prendre dans le cas de frères en esprit qui se sont unis par les liens du mariage avant notre arrivée dans le royaume de Tunis. Car nous craignons que les séparer engendrerait soit un grand scandale soit une apostasie dangereuse dans laquelle ils pourraient facilement sombrer. Ceci est particulièrement vrai dans le cas où les prêtres sous l'autorité desquels ils se trouvaient placés lorsqu'ils ont contracté [le mariage], lorsqu'ils les ont consultés à ce sujet, ne les ont pas dissuadés de le faire ni ne le leur ont interdit ; au contraire ils ont accordé leur autorité au contrat en célébrant le mariage à la face de l'Église.

Nous répondons : s'il est possible de le faire sans scandale ou risque d'apostasie, séparez ce genre de couples. Dans le cas contraire, accordez, dans le secret du confessionnal, une dispense à ceux qui ont contracté de tels mariages et empêcher strictement et publiquement les autres de faire de même.

13. Également, les Aromes ${ }^{154}$, dont nous avons la charge, sont très prompts à prêter serment sur des sujets légitimes, par exemple sur le fait de ne pas boire de vin ou d'autres choses semblables. Ensuite, ils se retrouvent incapables de respecter ces serments sauf en faisant un gros effort sur eux-mêmes. Ensuite, ils rompent leurs vœux de leur propre autorité sauf si c'est nous qui les absolvons de leurs vœux. Nous demandons donc s'il est possible, en certaines occasions, de les dispenser de tels vœux.

Nous répondons : on peut les dispenser de tels vœux en modifiant la pénitence. Et empêchez-les d'être enclins à prêter ce genre de serments.

14. Également, comment nous faut-il procéder avec ceux qui prêtent de l'argent ou d'autres choses en en les confiant à la mer et à ses risques; lorsqu'ils prennent plus qu'ils ne donnent, cela doit-il être considéré comme de l'usure ?

Nous répondons : il faut observer la nouvelle Décrétale « Naviganti ». 155

15. Également, au sujet de la dispense de ceux qui, après avoir été marqués du signe de la croix, viennent en pays sarrasin et plus tard, pour de nombreuses et diverses raisons ne peuvent respecter le serment des croisés, soit parce qu'ils se sont mariés là-bas sans

${ }^{154}$ A propos des Aromes (ailleurs appelés Aramos, Arrones, Atronii ou Atronies), voir introduction, supra.

${ }^{155}$ X V, 19, 19. 
révéler qu'ils étaient marqués de la croix, soit parce qu'ils n'osent pas rentrer par crainte des Sarrasins.

Nous répondons : un autre type de pénitence doit être imposé à ceux qui sont marqués de la croix et qui, pour cause de maladie, pauvreté ou par crainte sont incapable de respecter leur vœu. Les autres, qui sont pris par d'importantes tâches, ne doivent pas assumer de nouvelles charges mais une fois accomplis leurs autres devoirs, ils devront respecter leur vœu.

16. Également, nous est-il permis de célébrer la messe avant l'aube en raison de la crainte qu'éprouvent ceux dont nous avons la responsabilité, surtout à Pâques, période durant laquelle nous n'avons pas suffisamment de temps pour célébrer les offices sacrés et donner la communion au peuple?

Nous répondons : vous pouvez le faire de temps en temps à cause de la crainte qu'inspirent les Sarrasins ; autrement non, à l'exception de la veille de Noël.

17. Également, est-il permis de célébrer la messe à ceux n'ont pas dormi entre leur repas de la veille et l'heure de la messe, soit parce qu'il leur a été impossible de le faire, soit parce qu'ils étaient occupés à des taches licites?

Nous répondons : c'est possible si celui qui célèbre la messe estime qu'il a digéré sa nourriture.

18. Également, est-il permis de célébrer [la messe] avec des vêtements et de la vaisselle qui n'ont pas été bénis lorsque c'est nécessaire?

Nous répondons : ce n'est pas permis.

19. Également, nous est-il permis de consacrer chrisme et huile pour les malades et pour les catéchumènes avec seulement un ou deux compagnons puisque nous ne pouvons en avoir plus?

Nous répondons : il est permis à l'évêque de le faire.

20. Également, puisque grâce à l'indulgence de sa Sainteté le [Pape] Honorius [III] il nous est permis d'absoudre les excommuniés qui ne sont pas en mesure de se rendre facilement au Siège apostolique pour y être absous, nous demandons ce que "facilement" signifie dans ce cas et si nous pouvons absoudre les excommuniés dont on n'exige pas qu'ils se rendent à la curie s'ils promettent en premier lieu que dès qu'ils pourront ils exécuteront les ordres de l'église en présence de leurs prélats et ce, afin que leur absolution soit maintenue. Voilà ce que nous avons fait, avec notre conscience pour nous, jusqu'à maintenant. Autrement, comment devrions-nous procéder ?

Nous répondons : il faut comprendre que ceux qui ne peuvent "facilement" s'y rendre sont ceux qui ont en sont réellement empêchés comme par une maladie, un âge avancé, une grande pauvreté, etc. : de cela est plus apte à juger celui qui accorde prudemment la dispense que l'expression verbale.

Ceux dont on n'exige pas qu'ils se rendent à la curie mais plutôt qu'ils soient absous par leurs prélats, vous pouvez les absoudre parce que sa Sainteté le pape vous a concédé cette possibilité, pour aussi longtemps qu'ils sont résidents. L'absolution donnée par vous jusqu'à maintenant dans le cas de telles personnes ou par ces moines qui se trouvaient au royaume du Maroc n'est pas valable parce qu'ils n'étaient ni vos sujets ni les leurs et que nulle permission ne vous fut accordée pas plus qu'à eux. Ceux qui ont été absous de cette façon devront donc être renvoyés à leurs prélats ou à ceux auxquels le pouvoir d'absoudre ces gens a été dévolu. 
21. Également, ceux qui volent la dîme des Sarrasins sont-ils obligés de la leur rendre? Nous répondons : ils sont obligés de la leur rendre.

22. De la même façon, sont-ils contraints de payer les dettes qu'ils ont contractées par l'intermédiaire de l'usure?

Nous répondons : ils sont contraints de les payer.

23. Également, nous avons des doutes concernant d'autres sujets. Premièrement, ceux qui transportent du fer d'un pays sarrasin à un autre sont-ils excommuniés ?

Nous répondons : non, sauf si ceci est fait au détriment de la Terre sainte ou d'autres manières contre les chrétiens.

24. Également, [qu'en est-il] de ceux qui transportent des Sarrasins armés?

Nous répondons comme ci-dessus.

25. Également, certains transportent de petits morceaux de bois. Nous nous demandons s'il faut considérer cela comme du bois interdit par le canon.

Nous répondons : s'il est utilisé pour les navires ou les machines de guerre pour combattre les chrétiens ou au détriment de la Terre sainte, ils sont excommuniés.

26. Également, certains transportent de l'étoupe, du chanvre, de la poix, des cordes et autres matières du même genre.

Nous répondons comme ci-dessus, directement.

27. Également, les petits couteaux et les clous minuscules - ceux qui en vendent sont-ils excommuniés?

Nous répondons comme ci-dessus.

28. Également, certaines personnes, qui ne sont pas prélats, capturent des voleurs qui sont clercs et les fouettent. Ces personnes sont-elles excommuniées ? Si oui, pouvonsnous les absoudre?

Nous répondons : elles le sont, sauf si elles ont fait cela sur les ordres d'un prélat, et la rébellion de tels clercs rend cela nécessaire. Vous pouvez cependant les absoudre si l'on vous a accordé la permission de le faire, autrement non.

29. Également, il y a des gens qui veulent échanger un couteau contre un arc ou le contraire, ou quelque chose de semblable : ceux qui font cela sont-ils excommuniés ?

Nous répondons : non, sauf s'ils le font au détriment de la Terre sainte ou pour combattre les chrétiens.

30. Également, qui faut-il considérer comme "résidents" ? ceux qui restent un an ? un an et demi?

Nous répondons : ceux qui ont l'intention de rester là-bas, surtout s'ils y ont déjà séjourné pendant un an.

31. Également, puisque l'indulgence nous permet d'effectuer des absolutions en cas de nécessité, nous nous demandons ce que cela signifie : cela inclut-il les fièvres et les infections?

Nous répondons : lorsqu'il y a risque de mort ou possible risque de mort. 
32. Également, que faire avec les clercs qui sont des marchands puisqu'ils sont cause de scandale?

Nous répondons : leurs prélats doivent les en empêcher au moyen de la censure ecclésiastique ou d'un autre châtiment canonique.

33. Également, certains convoient des biens interdits sans savoir qu'ils sont interdits. Sont-ils excommuniés et si oui, pouvons-nous les absoudre?

Nous répondons : puisqu'il s'agit de biens interdits publiquement par les deux conciles, il n'est pas permis d'ignorer cela. Ils sont cependant absous avec une pénitence allégée.

34. Également, [que faire] de ceux qui transportent des biens interdits et qui, dès qu'ils apprennent qu'ils sont interdits, les remportent et refusent de les vendre aux Sarrasins?

Nous répondons : ils ne sont pas excommuniés.

35. De la même façon, certains apportent des biens interdits : ils en vendent une partie et l'autre reste à vendre. S'il arrive qu'ils soient absous par nécessité, quel conseil leur donner concernant l'autre partie [des biens] ?

Nous répondons : ils doivent la rendre.

36. De la même façon, certains demandent l'absolution du fait d'être un marchand maritime. Puissions-nous les absoudre?

Pouvons-nous les absoudre?

Nous répondons : non.

37. Également, d'autres donnent ou vendent des biens interdits aux Sarrasins sans savoir que pour cette raison ils sont excommuniés ; et dès qu'ils l'apprennent, ils reprennent leurs biens. Ces gens-là sont-ils excommuniés ? Si oui, peuvent-ils être absous?

Nous répondons : ils sont excommuniés mais ils doivent être absous.

38. Également, sommes-nous obligés d'éviter les personnes excommuniées avant qu'elles n'aient été dénoncées, comme le demandent certains ? Selon nous, d'après la loi, il semble que ce soit le contraire.

Nous répondons : il vous faut en effet les éviter, comme le veut la distinction que l'on trouve dans la décrétale Cum desideres. ${ }^{156}$

39. Également, comment nous faut-il comprendre ce qui est dit au sujet des Sarrasins qui sont en guerre avec des "chrétiens" : cela signifie-t-il [qu'ils sont en guerre] avec un roi, une cité ou avec l'Église ? Comment faut-il comprendre cela?

Nous répondons : avec tout chrétien.

40. De plus : quelqu'un est obligé par une dette, pour sa subsistance ou pour d'autres raisons, et il ne possède rien ni n'a le moyen de gagner de l'argent. Poussé par cette nécessité, il embarque à bord d'un navire comme marin afin de gagner sa vie et de payer ses dettes ; ce bateau transporte des biens interdits en terre sarrasine et il n'a pas pu trouver d'autres manières de gagner un salaire. Cet homme est-il excommunié, en

156 X V, 39, 15. 
particulier étant donné qu'il tire plus de profit de son salaire que ce qu'il dépense ou ce qu'il doit, peut-être cinq deniers, plus ou moins.

Nous répondons : ils sont excommuniés car ils prennent part au délit avec ceux qui envoient ou transportent [les marchandises interdites], leur apportant aide et coopération, même si ce n'est que pour un salaire. Mais pour attribuer l'amende pécuniaire ou le châtiment, agissez moins sévèrement avec eux selon ce que votre discrétion jugera bon à faire.

Donné à Pérouse le 14e jour des calendes de février, la 8e année du pontificat de Sa Sainteté Grégoire.

\section{John TOLAN}

John Tolan is professor of Medieval History at the University of Nantes (France) and author of numerous articles and books in medieval history and cultural studies, including Petrus Alfonsi and his Medieval Readers (1993) Saracens: Islam in the Medieval European Imagination (2002), Sons of Ishmael: Muslims through European Eyes in the Middle Ages (2008), Saint Francis and the Sultan: The Curious History of a ChristianMuslim Encounter (2009), and (with Gilles Veinstein and Henry Laurens) Europe and Islam (2012). He currently is director of a major project funded by the European Research Council, "RELMIN: The legal status of religious minorities in the EuroMediterranean world (5th-15th centuries)" (www.relmin.eu).

\section{Laurence FOSCHIA}

Former student of the École normale supérieure de Paris and former Member of the French School of Archaeology in Athens, agrégée in Classics, Laurence Foschia defended her PhD (Greek Studies) in 2006 at the Université of Paris IV-Sorbonne. It was titled: "Le polythéisme grec dans l'Antiquité tardive : étude des cultes et sanctuaires de Grèce propre (fin IIIe-VIIe siècle)" (to be published at Brill). She notably published:

"The Preservation, Restoration, and (Re)constructions of Pagan Cult Places in Late Antique Greece (4th-5th c.)", Journal of Late Antiquity 2 (2009), p. 209-223 and "Chrétiens, païens, rabbins dans le même bain ? Les bains dans l'Orient romain (IVe-VIIe siècle)", in M.-F. M.-F. Boussac et al. (eds.), Acts of the 3rd 'Balnéorient' Symposium, Damascus, 2009 (with G. Bady, to be published).

This publication is part of the research project RELMIN "“The Legal Status of Religious Minorities in the Euro-Mediterranean World ( $5^{\text {th }}-15^{\text {th }}$ centuries)"

The research leading to this publication has received funding from the European Research Council under the European Union's Seventh Framework Progamme (FP7/2007-2013) /ERC grant agreement n²49416. 